\title{
Rancang Bangun Aplikasi Belajar Membaca Al-Qur'an Berbasis Android
}

\author{
Fadhil Naufal Shodiq ${ }^{1}$, Rachmat Adi Purnama ${ }^{2}$, Sujiliani Heristian ${ }^{3}$ \\ Program Studi Teknologi Komputer, Fakultas Teknik dan Informatika \\ Universitas Bina Sarana Informatika \\ J1. Kramat Raya No.98, Jakarta Pusat, DKI Jakarta 10450, Indonesia
}

e-mail: ${ }^{1}$ fadhil.shodiq18@gmail.com, ${ }^{2}$ rachmat.rap@ bsi.ac.id, ${ }^{3}$ sujiliani.she@bsi.ac.id

\begin{tabular}{l|l|l|l|} 
Artikel Info : Diterima : 02-12-2020 & Direvisi : 10-12-2020 & Disetujui : 04-01-2021
\end{tabular}

\begin{abstract}
Abstrak - Membaca Al-Quran sejak dulu telah menjadi budaya masyarakat Indonesia, namun akhir-akhir ini mengaji sudah mulai ditinggalkan. Umat Islam lebih asik mengikuti Game dan social media dengan asik bermain dari pada membuka mushaf Al-Quran. Agar tidak terjadinya generasi muda buta huruf hijaiyah, harus melakukan pembelajaran yang mengikuti zaman sekarang, seperti aplikasi pembelajaran yang tidak kalah dengan aplikasi yang membuat generasi muda muslim bermalas-malasan, target utama dalam metode pembelajaran aplikasi membaca Al-Quran adalah anak di usia dini untuk mempelajarinya karena anak diusia dini mempunyai daya tangkap dan daya ingat yang cukup baik. Berdasarkan latar belakang yang penulis sampaikan di atas, maka penulis tertarik untuk melakukan penelitian lebih lanjut terhadap metode pembelajaran berbasis aplikasi membaca AlQuran. Metode pengembangan sistem yang digunakan dalam penelitian ini menggunakan Model RAD (Rapid Application Development). Rapid Application Development (RAD) adalah model proses pengembangan perangkat lunak yang bersifat inkremental terutama untuk waktu pengerjaan yang pendek. Hasil dari penelitian didapat bahwa pembelajaran dengan sistem interaktif meningkatkan minat anak dalam memulai proses awal belajar. Selain itu games interaktif menjadi suatu alternatif dalam menyampaikan pembelajaran diantara metodemetode lainnya.
\end{abstract}

Kata Kunci : Aplikasi Belajar, Membaca Al-Qur'an, Android

Abstracts - Reading the Al-Qur'an has always been a culture of Indonesian society, however recently the Al-Qur'an has begun to be abandoned. Muslims are more engrossed in following games and social media with fun playing than opening the Al-Quran mushaf. In order not to have hijaiyah illiterate young people, they must carry out learning that follows the present era, such as learning applications that are not inferior to applications that make young Muslims lazy, the main target in the learning method of reading the Al-Quran application is children at an early age to learn it because children at an early age have quite good comprehension and memory. Based on the background that the authors convey above, the authors are interested in conducting further research on learning methods based on reading the Al-Quran application. The system development method used in this study uses the RAD (Rapid Application Development) Model. Rapid Application Development (RAD) is a software development process model that is incremental, especially for short processing times. The results of the research show that learning with an interactive system increases children's interest in starting the initial learning process. In addition, interactive games are an alternative in conveying learning among other methods.

Keywords : Applications Learning, Reading the Qur'an, Android

\section{PENDAHULUAN}

Mengaji Al-Quran sejak dulu telah menjadi budaya masyarakat Indonesia. Namu, akhir-akhir ini mengaji sudah mulai ditinggalkan. Umat Islam lebih asik mengikuti Game dan sosial media dengan asik bermain dari pada membuka mushaf Al-Quran. Masalah keinginan untuk belajar mengaji itu sangat jelas didasarkan perkembangan teknologi yang semakin cangih ini. Dampak dari perkembangan teknologi ini membuat masyarakat yang semakin banyak tidak biasa mengaji, baik itu dari kalangan tua maupun muda. Dalam hal ini membuat generasi-generasi muslim muda yang buta huruf hijaiyah. Sangat disanyangkan bilamana pemuda sekarang tidak mengaji, sedangkan Al Quran adalah pedoman hidup manusia.

This work is licensed under a Creative Commons Attribution-ShareAlike 4.0 International License. 
Dengan perkembangan teknologi saat ini, pemanfaatan teknologi yang baik akan sangat membantu untuk memberikan pembelajaran kepada anak-anak. Teknologi yang dirancang dan dikonsep sedemikian rupa akan sangat menarik minat anak-anak untuk menggunakannya (Aditama, Rosyid, \& Fahriani, 2018)

Pada model penelitian pengembangan dengan menggunakan model Dick and Carey yang terdiri dari sepuluh tahap yaitu, analisis kebutuhan dan tujuan, melakukan analisis instruksional, analisis pembelajar dan konteks, merumuskan tujuan performasi, mengembangkan instrumen, mengembangkan strategi instruksional, mengembangkan dan memilih material instruksional, merancang dan melakukan evaluasi formatif, melakukan revisi instruksional, dan merancang dan melaksakan evaluasi sumatif. Subyek dalam penelitian ini adalah siswa kelas IV SD Widya Bhakti. Hasil penelitian menunjukan adanya peningkatan hasil belajar. Hal ini dibuktikan dengan rata-rata hasil belajar siswa pada pretest yaitu 65,2 dan setelah menggunakan game interaktif nilai ratarata siswa menjadi 76,9 Hal ini menunjukkan kenaikan yang signifikan pada hasil belajar siswa. Implikasi dari penelitian ini adalah game interaktif pada pembelajaran tematik dapat digunakan sebagai interaktif dalam pebelaharan bagi guru dan siswa. Pada Hasil penelitian ini menunjukan adanya peningkatan hasil belajar siswa melalui game interatif (Clara, Supriyati, \& Situmorang, 2018) .

Hasil observasi dan wawancara dengan kepala sekolah dan guru, maka dapat dirumuskan permasalahan yaitu suasana pembelajaran dirasa kurang menarik siswa. Akar dari permasalahan ini adalah pembelajaran masih mengandalkan material cetak seperti buku dan lembar kegiatan siswa (LKS), tampilan power point atau terkadang siswa dipertontonkan tayangan VCD yang tidak interaktif. Dengan masalah di atas maka peserta dikenalkan pada program aplikasi yang dibuat dan dibimbing untuk membuat karakter game, membuat alur cerita game (story board), mengkonfigurasi gerakan dan efek, mengkonfigurasi skor dan mengkonfigurasi penghentian permainan. Dari kegiatan pelaksanaan pengabdian kepada masyarakat di MIM Potronayan 1 dan MIM PK Kenteng dapat ditarik kesimpulan sebagai berikut: (1) Media pembelajaran interaktif berbasis multimedia yang sudah dibuat dan diperkenalkan sudah bisa digunakan dalam kegiatan belajar mengajar disekolah mitra. Hasil monitoring menunjukkan media pembelajaran interaktif dan game edukatif mampu meningkatkan minat belajar siswa, (2) Guru-guru sudah diperkenalkan dasar-dasar proses pembuatan media pembelajaran sehingga bisa mengembangkannya sendiri untuk membuat media pembelajaran interaktif untuk mata pelajarannya sendiri (Supriyono, Murtiyasa, Rahmadzani, \& Syahriandi, 2018).

Media pembelajaran berfungsi sebagai salah satu sumber belajar bagi siswa untuk memperoleh pesan dan informasi yang berikan oleh guru sehingga materi pembelajaran dapat lebih meningkat dan membentuk pengetahuan bagi siswa (Nurrita, 2018). Fungsi dari media pembelajaran menurut (Arsyad \& Fatmawati, 2018) dapat dijelaskan sebagai berikut:

1. Fungsi atensi merupakan fungsi inti yaitu menarik dan mengarahkan perhatian mahasiswa untuk berkonsentrasi kepada isi pelajaran yang berkaitan dengan makna visual yang ditampilkan atau menyertai teks materi pelajaran.

2. Fungsi afektif yaitu dapat terlihat dari tingkat kenikmatan mahasiswa ketika belajar (atau membaca) teks yang bergambar. Gambar atau lambang visual dapat menggugah emosi dan sikap mahasiswa.

3. Fungsi kognitif yaitu terlihat dari temuan-temuan penelitian yang mengungkapkan bahwa lambang visual atau gambar memperlancar pencapaian tujuan untuk memahami dan mengingat informasi atau pesan yang terkandung dalam gambar.

4. Fungsi kompensatoris yaitu terlihat dari hasil penelitian bahwa media visual yang memberikan konteks untuk memahami teks membantu mahasiswa yang lemah dalam membaca untuk mengorganisasikan informasi dalam teks dan mengingatnya kembali. Dengan kata lain, media pembelajaran berfungsi untuk mengakomodasi mahasiswa yang lemah dan lambat menerima dan memahami isi materi yang disajikan dengan teks atau disajikan secara verbal.

Multimedia merupakan salah satu sumber belajar. Jenis media bermacam-macam dari yang sederhana seperti media kartu, sampai yang modern seperti komputer, internet, LCD, dan lain-lain. Berdasarkan indera yang digunakan peserta didik dalam memanfaatkan media pembelajaran. Media dapat dibagi menjadi tiga yaitu media audio, media visual, dan media audiovisual. (Marjuni \& Harun, 2019)

Multimedia merupakan perpaduan antara berbagai media (format file) yang berupa teks, gambar (vektor atau bitmap), grafik, sound, animasi, video interaksi dan lain-lain yang telah dikemas menjadi file digital (komputerisasi), digunakan untuk menyampaikan pesan kepada publik. Sedangkan pengertian interaktif terkait dengan komunikasi dua arah atau lebih dari komponen-komponen komunikasi. (Arsyad \& Fatmawati, 2018)

Menurut Rani, Kumar, Adarsh, Mohan, \& Kiran dalam (Wati \& Ernawati, 2018) Android merupakan kombinasi dari tiga komponen yaitu, sistem operasi yang open source untuk mobile, pengembangan platform yang open source untuk aplikasi mobile dan sistem operasi android ini memang dibuat untuk mobile phone. Android adalah sistem operasi yang bersifat open source. Sistem operasi ini memiliki lisensi Apache yang sangat terbuka dan bebas (Latifah \& Abimanyu, 2016). 
Android adalah sebuah sistem operasi untuk perangkat mobile berbasis linux yang mencakup sistem operasi, middleware dan aplikasi. Menurut Ichwan, M., Husada, M. G., \& Rasyid, M. I. A. dalam (Lubis \& Salim, 2016) Android menyediakan platform terbuka bagi para pengembang untuk menciptakan aplikasi mereka. Awalnya, Google Inc. membeli Android Inc. yang merupakan mendatang baru yang membuat peranti lunak untuk Handphone/smartphone. Kemudian untuk mengembangkan Android, dibentuklah Open Handset Alliance (OHA), konsorsium dari 34 perusahaan peranti keras, peranti lunak, dan telekomunikasi, termasuk Google, HTC, Intel, Motorola, Qualcomm, T-Mobile, dan Nvidia.

Menurut (Sukamto, 2019) "Rapid Application Development (RAD) adalah model proses pengembangan perangkat lunak yang bersifat inkremental terutama untuk waktu pengerjaan yang pendek. Model RAD adalah adaptasi dari model air terjun versi keceptan tinggi dengan menggunakan model air terjun untuk pengembangan setiap komponen perengakat lunak.

\section{METODE PENELITIAN}

Dalam penulisan ini penulis menggunakan dua metode yaitu pengembangan perangkat lunak dan teknik pengumpulan data:

A. Metode Pengembangan Perangkat Lunak

Metode pengembangan sistem yang digunakan dalam penelitian ini menggunakan Model RAD (Rapid Application Development). Rapid Application Development (RAD) adalah model proses pengembangan perangkat lunak yang bersifat inkremental terutama untuk waktu pengerjaan yang pendek. Model RAD adalah adopsi dari model air terjun versi kecepatan tinggi dengan menggunakan model air terjun untuk pengembangan setiap komponen perangkat lunak. (Sukamto, 2019).

Berikut adalah tahapan-tahapan yang dilakukan dalam pengembangan sistem.

1. Requirements Planning (Perencanaan Persyaratan)

Pada tahap ini penulis menganalisa permasalahan yang terjadi dan kebutuhan perangkat lunak agar dapat dipahami seperti apa yang dibutuhkan oleh pengguna (user). Proses ini dimulai dengan membuat gambaran apa yang dapat dilakukan oleh User. Direncanakan form yang akan dibuat adalah form tampilan awal, form nenu yang berisikan Huruf Hijaiyah, Tanda Baca, Game, Kuis, Tentang dan Profil.

2. RAD Design Workshop (Pemodelan)

Dalam menggambarkan skenario program aplikasi ini penulis meggunakan storyboard, state transition diagram, diagram alir (flowchart), dan grafik untuk menggambarkan suatu proses dihubungkan satu sama lain dalam waktu yang bersamaan.

3. Implementasi

Tahap Code Generation atau coding merupakan tahap pengkodean dari desain ke dalam suatu bahasa pemrograman. Dalam tahap ini desain yang telah dibuat dikodekan dengan menggunakan bahasa pemrograman terstuktur.

B. Teknik Pengumpulan Data

Untuk mendukung penyusunan penelitian ini penulis membutuhkan data sebagai dasar dalam penelitian dan evaluasi. Untuk mendapatkan data-data tersebut, penulis mengambil metode sebagai berikut:

1. Pengamatan Langsung (Observation)

Penulis melakukan riset langsung kepada anak usia dini untuk mengumpulkan data dengan cara pengamata langsung dan melihat kendala apa saja yang terjadi pada metode pembelajaran membaca Al Qur'an.

2. Wawancara (Interview)

Metode yang dilakukan dengan melakukan tanya jawab secara langsung kepada anak usia dini sehubungan dengan judul yang penulis ambil dalam penulisan penelitian ini.

3. Studi Pustaka (Library research)

Penulis mencari refrensi dengan cara membaca dan mempelajari buku-buku yang ada diperpustakaan, internet serta tempat bacaan lainnya yang berhubungan dengan pembahasan pada penelitian ini. Sumber-sumber bacaan penulis berasal dari buku ahli yang digunakan untuk melengkapi dan mencari refrensi yang berkaitan dengan judul penelitian.

\section{HASIL DAN PEMBAHASAN}

Pengenalan bacaan huruf hijaiyah dan tanda bacaannya yang berbasis android sangat bermanfaat dalam mempermudah mempelajarinya khusus anak-anak yang senang dan tidak membosankan karena didukung dengan 
gambar-gambar yang menarik.

Dalam penulisan ini proses pembuatan programnya sesuai dengan model yang sudah ditentukan terlebih dahulu yaitu model Model RAD (Rapid Application Development) dengan tahapan:

\section{A. Requirements Planning (Perencanaan Persyaratan)}

\section{Analisa Kebutuhan User}

Tahap ini dimulai dengan menganalisa kebutuhan user yaitu:

a. User dapat masuk ke Aplikasi Belajar Membaca Al-Qur'an Berbasis Android yang sudah terinstal pada smartphone.

b. User dapat melihat menu Aplikasi Belajar Membaca Al-Qur'an Berbasis Android yaitu Menu Huruf Hijaiyah, Tanda Baca, Game, Kuis, Tentang Game dan Profil.

c. User dapat melihat Huruf Hijaiyah.

d. User dapat melihat Tanda Baca.

e. User dapat menjalankan Game.

f. User dapat mengikuti Kuis.

g. User dapat melihat Tentang Game.

h. User dapat melihat Profil Pembuat Game.

i. User dapat keluar dari Aplikasi Belajar Membaca Al-Qur'an Berbasis Android.

2. Analisa Kebutuhan Software dan Hardware

Software yang digunakan dalam membuat aplikasi ini adalah sebagai berikut:
a. Operating System
: Windows 10
b. Aplikasi Android
: Android Studio Versi 3.6.3
c. Database
: SQL Xampp Versi 5.6.21-VC11
d. Aplikasi Edit Foto
: Adobe Photoshop CS6

Hardware minimal yang digunakan untuk dapat membuat aplikasi ini adalah Personal Computer (PC) dengan spesifikasi sebagai berikut:
a. Processor
: Berkecepatan 2.4 Ghz (Pentium IV)
b. RAM
: Berkapasitas $512 \mathrm{MB}$
c. Harddisk
: Memiliki sisa ruang $1 \mathrm{~GB}$
d. Sound Card
: 2.0 Channel
e. Speaker
: Standart Stereo Speaker atau headset
f. Keybord
: Standart
g. Mouse
: Standart

\section{Smartphone}

Smartphone minimal yang digunakan untuk dapat menjalankan aplikasi ini adalah smartphone yang berbasis android minimal versi 4.0 ice cream sandwich.

\section{B. RAD Design Workshop (Pemodelan)}

Dalam merancang sebuah sistem dalam pembuatan aplikasi pembelajaran ini harus berpedoman pada karekteristik dan unsur yang terdapat pada aplikasi tersebut yaitu:

\section{Format}

Game interaktif ini terdiri dari empat elemen utama yaitu huruf hijaiyah, tanda baca, game dan kuis. Pada menu huruf hijaiyah akan tampil layar belajar huruf hijaiyah dari Alif sampai $Y a$ yang apabila di klik salah satu huruf akan keluar suara. Pada menu tanda baca terbagi menjadi dua yaitu Harokat dan Tanwin, jika dipilih Harokat akan tampil Harokat yang apabila di klik Harokatnya akan keluar suara. Didalam menu game terdapat permainan berupa mencocokkan huruh hijaiyah dengan bacaan dengan huruf latin, game ini sebanyak 10 soal. Didalam menu kuiz terdapat soal sebanyak 10, setelah selesai menjawab diakhir pertanyaan pengguna akan mendapatkan skor dan nilai.

2. Rules

Pada aplikasi ini terdapat materi berupa pengenalan huruf hijaiyah dan evaluasi yaitu berupa mencocokkan huruh hijaiyah dengan bacaan dengan huruf latin sebanyak 10 soal. Didalam evaluasi tiap soal yang benar akan mendaptkan nilai 10 dan user harus menyelesaikan semua pertanyaan untuk bisa kembali ke menu utama.

3. Policy

Dalam kebijakan ini penulis telah membuat evaluasi. Dengan memilh tombol game mencocokkan huruh hijaiyah dengan bacaan dengan huruf latin sebanyak 10 soal maka pengguna akan diharuskan menjawab soal 
dengan benar. Selain itu, setelah menjawab semua soal akan tampil skor dan nilai. Jika user sudah menyelesaikan soal sebanyak 10 maka akan tampil dilayar Hasil dan ada pilihan "Keluar" atau "Coba Lagi".

4. Scenario

Pada saat sudah masuk kedalam Game interaktif ini maka akan terdapat enam pilihan menu yaitu huruf hijaiyah, tanda baca, game, kuis, tentang dan profil. Pada menu huruf hijaiyah akan tampil layar belajar huruf hijaiyah dari Alif sampai $Y a$ yang apabila di klik salah satu huruf akan keluar suara. Pada menu tanda baca terbagi menjadi dua yaitu Harokat dan Tanwin, jika dipilih Harokat akan tampil Harokat yang apabila di klik Harokatnya akan keluar suara. Didalam menu game terdapat permainan berupa mencocokkan huruh hijaiyah dengan bacaan dengan huruf latin, game ini sebanyak 10 soal. Didalam menu kuiz terdapat soal sebanyak 10, setelah selesai menjawab diakhir pertanyaan pengguna akan mendapatkan skor dan nilai. Menu game dan kuis adalah evaluasi bagi user untuk mengukur kemampuan user setelah mempelajari huruf hijaiyah dan tanda bacanya.

5. Score Model

Dalam menu game setiap soal bernilai score 10 apabila di jawab dengan benar dan score 0 jika salah. Nilai keseluruhan akan tampil di akhir state.

6. Indicators

Indikasi keberhasilan user dalam penggunaan program ini ditentukan pada soal-soal yang berhasil di jawab. Dapat dikatakan berhasil jika user mendapatkan nilai di atas 80 pada menu evaluasi.

7. Symbols

Terdapat tombol-tombol pada menu berupa tombol yang digunakan untuk menuju ke menu-menu yang disediakan. Untuk masuk ke halaman menu user harus memilih tombol yang sudah disediakan. Di setiap frame ada tombol kembali untuk kembali ke halaman sebelumnya kalau ingin keluar maka pengguna pilih tombol keluar.

Perancangan story board berisi terjemahan berupa gambar cerita naskah dari program yang dibuat oleh penulis dengan menggunakan tulisan dan gambar. Berikut ini penulis ceritakan alur dari program animasi belajar membaca:

1. Story Board Opening

Gambaran dari story board halaman awal, yang akan dijelaskan oleh gambar berikut ini:

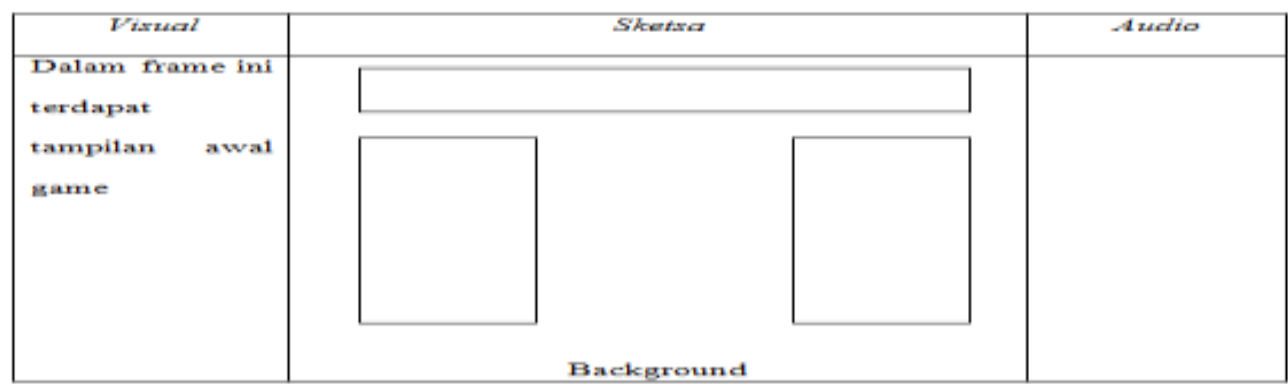

Gambar 1. Story Board Opening

2. Story Board Menu Pilihan

Gambaran dari story board menu pilihan, yang akan dijelaskan oleh gambar berikut ini:

\begin{tabular}{|c|c|c|c|c|}
\hline Visual & \multicolumn{3}{|c|}{ Sketsa } & Audio \\
\hline $\begin{array}{ll}\text { Dalam frame } & \text { ini } \\
\text { terdapat enam pilihan }\end{array}$ & Huruf Hijaiyah & Tanda Baca & Game & \\
\hline yaitu : Huruf Hijaiyah, & & & & \\
\hline Tanda Baca, Game, & Kuis & Tentang & Profit & \\
\hline $\begin{array}{l}\text { Kuis, Tentang dan } \\
\text { Profi1 }\end{array}$ & & Background & & \\
\hline
\end{tabular}

Gambar 2. Story Board Menu Pilihan

3. Story Board Menu Huruf Hijaiyah

Gambaran dari story board menu huruf hijaiyah, yang akan dijelaskan oleh tabel berikut ini:

Tabel 1. Story Board Menu Huruf Hijaiyah

\begin{tabular}{|c|c|c|c|c|c|c|}
\hline Visual & \multicolumn{5}{|c|}{ Sketsa } & Audio \\
\hline & Ja & Tsa & Ta & Ba & Alif & \\
\hline
\end{tabular}




\begin{tabular}{|c|c|c|c|c|c|}
\hline \multirow{5}{*}{$\begin{array}{c}\text { Dalam frame ini } \\
\text { terdapat } 29 \text { pilihan } \\
\text { yaitu Alif sampai Ya }\end{array}$} & $\mathrm{Ra}$ & Dzal & $\mathrm{Da}$ & Kha & $\mathrm{Ha}$ \\
\hline & Shad & shad & Syin & Sin & Zay \\
\hline & $\mathrm{Fa}$ & Ghayn & Ain & Zha & Tha \\
\hline & Nun & Mim & Lam & Kaf & Gaf \\
\hline & & ya & hamzah & ha & waw \\
\hline
\end{tabular}

\section{User Interface}

Pada pembuatan game interaktif ini dikarenakan fungsinya yang bersifat pembelajaran, aplikasi ini dibuat tidak terlalu berlebihan sehingga user mampu mengoprasikan aplikasi ini dengan baik dan mudah. Tampilan user interface ini antara lain :

1. Tampilan Halaman Pembukaan

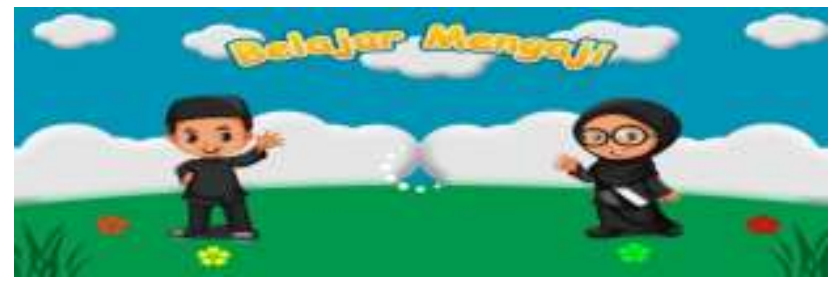

Gambar 3. Tampilan Halaman Pembukaan

2. Tampilan Menu Utama

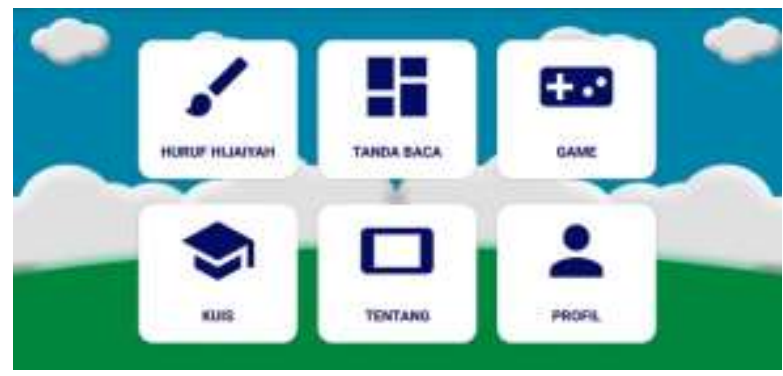

Gambar 4. Tampilan Menu Utama

3. Tampilan Menu Huruf Hijaiyah

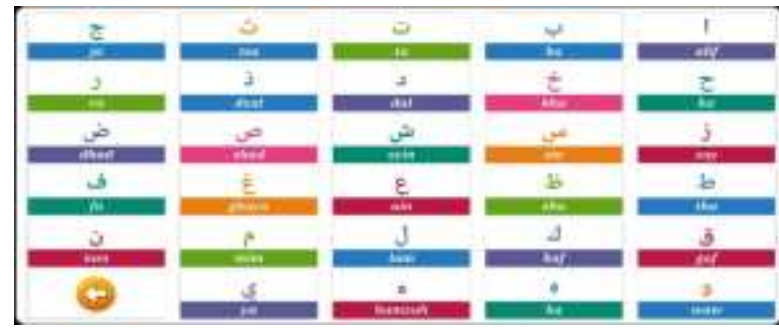

Gambar 5. Tampilan Menu Huruf Hijaiyah

4. Tampilan Menu Tanda Baca

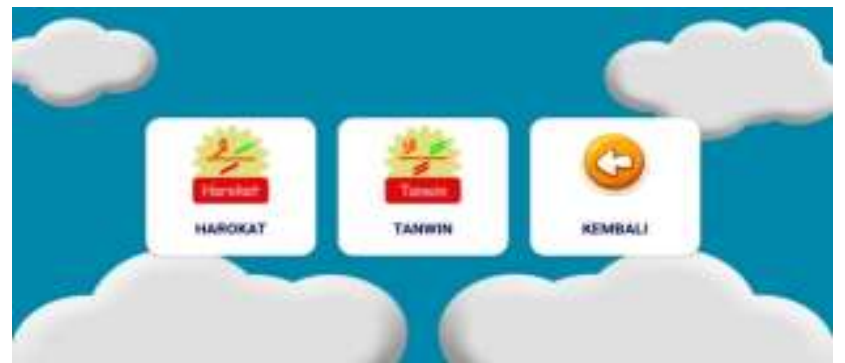

Gambar 6. Tampilan Menu Tanda Baca 
5. Tampilan Menu Harokat

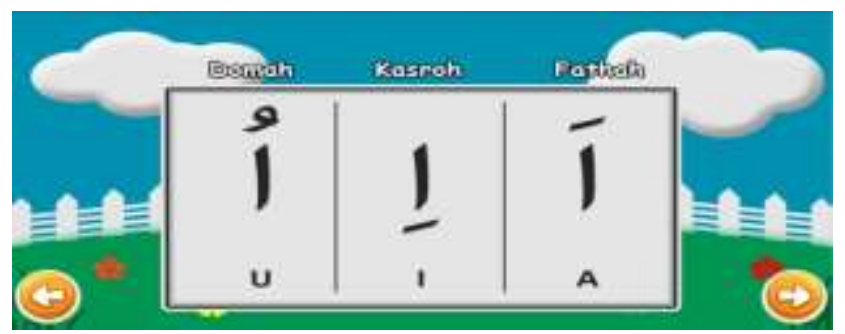

Gambar 7. Tampilan Menu Harokat

\section{State Transition Diagram}

State Transition Diagram adalah suatu permodelan peralatan (modeling tool) yang menggambarkan sifat ketergantungan terhadap suatu system waktu nyata (real time system), dan tampilan tatap muka (interface) pada sistem aktif (online system). Pemodelan ini juga penulis gunakan dalam menjelaskan alur-alur dari program yang penulis rancang.

1. Scene Menu Utama

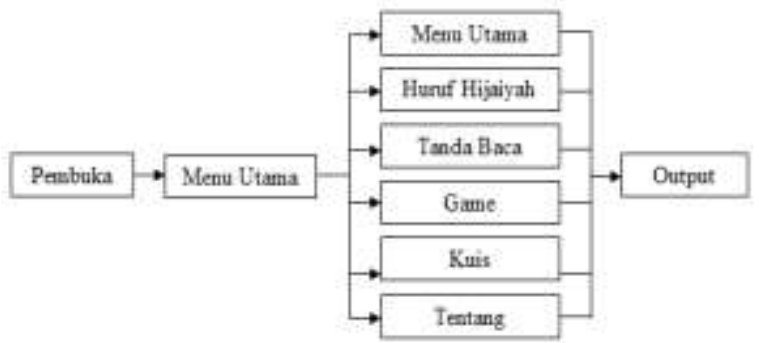

Gambar 8. Scene Menu Utama

2. Scene Menu Huruf Hijaiyah

$$
\text { Pembaka } \rightarrow \text { Mend Utama } \rightarrow \text { Huruf Hijayah } \rightarrow \text { Kenbali }
$$

Gambar 9. Scene Menu Huruf Hijaiyah

\section{E. Diagram Alur (Flow Chart)}

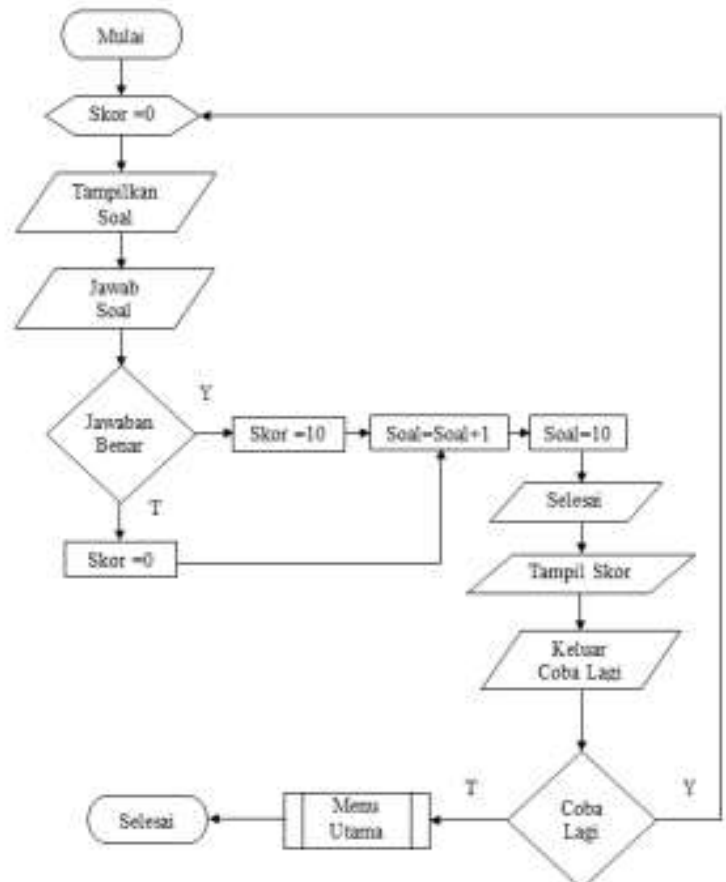

Gambar 10. Flow Chart Game 


\section{F. Implementasi}

1. Code Generation

\section{a.. App Hijaiyah}

$<$ ?xml version $=" 1.0 "$ encoding $=" U T F-8 " ?>$

$<$ module external.linked.project.id="AppHijaiyah"

external.linked.project.path $=" \$ M O D U L E \_D I R \$ "$

external.root.project.path="\$MODULE_DIR\$" external.system.id="GRADLE" type="JAVA_MODULE" version="4">

$<$ component name $="$ FacetManager" $>$

$<$ facet type $="$ java-gradle" name $="$ Java-Gradle" $>$

$<$ configuration>

$<$ option name $=" B U I L D \_F O L D E R \_P A T H "$ value $=" \$ M O D U L E \_D I R \$ /$ build $" />$

$<$ option name $=" B U I L D A B L E "$ value $="$ false" />

$</$ configuration $>$

$</$ facet $>$

$</$ component $>$

$<$ component name $=" N e w M o d u l e R o o t M a n a g e r " L A N G U A G E \_L E V E L=" J D K \_1 \_7 "$ inherit-compiler-output="true" >

<exclude-output $/>$

$<$ content url="file://\$MODULE_DIR\$">

< excludeFolder url="file://\$MODULE_DIR\$/.gradle" />

$</$ content $>$

$<$ orderEntry type $="$ inheritedJdk" / >

$<$ orderEntry type $=$ "sourceFolder" forTests="false" />

$</$ component $>$

$</$ module $>$

\section{Build Gradle}

// Top-level build file where you can add configuration options common to all sub-projects/modules.

buildscript \{

repositories \{

google()

jenter()

j

dependencies \{

classpath 'com.android.tools.build:gradle:3.0.1'

// NOTE: Do not place your application dependencies here; they belong

$/ /$ in the individual module build.gradle files

\}

\}

allprojects \{

repositories \{

google()

jcenter()

maven \{ url "https://jitpack.io" \}

\}

task clean(type: Delete) \{

delete rootProject.buildDi

j

\section{G. Pengujian White Box}

Dalam hal ini, pengujian tidak dilakukan terhadap keselurahan program secara utuh, namun dilakukan sampel pengujian terhadap scene huruf hijaiyah dan kuis.

1. Pengujian Menu Huruf Hijaiyah.

a. Pilih menu Huruf Hijaiyah di menu utama.

b. Tampil scene pengenalan Huruf Hijaiyah.

c. Pilih salah satu Huruf Hijaiyah.

d. Akan mengeluarkan suara sesuai dengan bacaan Huruf Hijaiyah.

e. Tekan Tanda panah untuk kembali ke Menu Utama.

2. Pengujian Menu Tanda Baca.

a. Pilih menu Tanda Baca di menu utama.

b. Akan ada pilihan Harokat dan Tanwin.

c. Pilih salah satu.

d. Tampil scene Harokat atau Tanwin.

e. Akan mengeluarkan suara sesuai dengan bacaan Harokat dan Tanwin.

f. Tekan Tanda panah untuk kembali ke Menu Utama.

3. Pengujian Game

a. Pilih menu Game di menu utama.

b. Tampil soal game.

c. Pilih salah satu jawaban. 
d. Jika usera berhasil menjawab pertanyaan dengan benar, maka user akan mendapatkan skor 10 di masingmasing soal. Namun jika salah akan mendapatkan nilai 0 tiap soalnya. Skor tersebut di akumulasikan di akhir soal.

\section{H. Hasil Pengolahan Data Kuesioner Uji Coba Aplikasi}

Uji coba aplikasi belajar membaca Al-Qur'an berbasis android yang telah dibuat diberikan kepada para guru dan siswa sebanyak 10 responden. Dengan cara memberikan masing-masing 8 pertanyaan untuk dijadikan tolak ukur seberapa besar pengaruh proses pengajaran dan pembelajaran setelah menggunakan aplikasi ini.

Berikut ini adalah pertanyaan yang diberikan kepada responden:

Tabel 2. Kuesioner aplikasi belajar membaca Al-Qur'an berbasis android

\begin{tabular}{|c|c|c|c|}
\hline $\begin{array}{l}\text { No } \\
\text { Soal }\end{array}$ & Pertanyaan & YA & $\begin{array}{l}\text { TID } \\
\text { AK }\end{array}$ \\
\hline 1 & $\begin{array}{l}\text { Apakah aplikasi ini mudah } \\
\text { digunakan? }\end{array}$ & & \\
\hline 2 & $\begin{array}{l}\text { Apakah aplikasi ini sesuai } \\
\text { dengan judul? }\end{array}$ & & \\
\hline 3 & $\begin{array}{l}\text { Menurut anda apakah soal } \\
\text { pada kuis sulit? }\end{array}$ & & \\
\hline 4 & $\begin{array}{l}\text { Menurut anda apakah suara } \\
\text { terdengar jelas? }\end{array}$ & & \\
\hline 5 & $\begin{array}{l}\text { Apakah aplikasi ini } \\
\text { memudahkan anda dalam } \\
\text { belajar? }\end{array}$ & & \\
\hline 6 & $\begin{array}{l}\text { Apakah jumlah soal yang } \\
\text { ditanyakan kurang? }\end{array}$ & & \\
\hline 7 & $\begin{array}{l}\text { Menurut anda apakah } \\
\text { aplikasi ini membosankan? }\end{array}$ & & \\
\hline 8 & $\begin{array}{l}\text { Apakah aplikasi ini } \\
\text { menarik? }\end{array}$ & & \\
\hline
\end{tabular}

Dari hasil pertanyaan yang disampaikan kepada responden didapat data yang diolah dan menghasilkan grafik sebagai berikut:

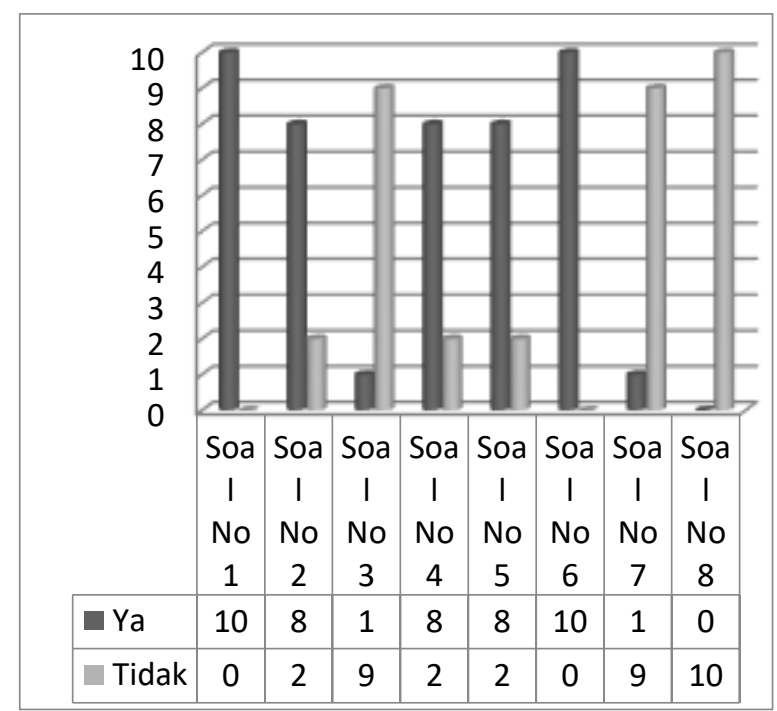

Gambar 11. Grafik Hasil Pengolahan Kuesioner

Dari hasil kuesioner pada gambar diatas dapat diambil kesimpulan sebagai berikut:

a. Soal nomor 1 menunjukkan bahwa aplikasi ini mudah digunakan.

b. Soal nomor 2 menunjukkan bahwa aplikasi ini sesuai dengan judul sekalipun ada 2 pengguna yang tidak setuju.

c. Soal nomor 3 menunjukkan bahwa kuis soal latihan berupa pilihan ganda dalam aplikasi ini mudah.

d. Soal nomor 4 menunjukkan bahwa suara dalam aplikasi ini terdenganr sangat jelas.

e. Soal nomor 5 menunjukkan bahwa pengguna di mudahkan jika belajar menggunakan aplikasi ini.

f. Soal nomor 6 menunjukkan bahwa jumlah soal dalam kuis sudah cukup. 
g. Soal nomor 7 menunjukkan bahwa aplikasi ini menarik

h. Soal nomor 8 menunjukkan bahwa aplikasi ini telah berhasil membuat pengguna lebih mengerti.

Dan kesimpulan bahwa sebagian besar pengguna dapat menggunakan aplikasi ini dengan mudah dan dapat membantu pengguna.

\section{KESIMPULAN}

Berdasarakan pembuatan Aplikasi Belajar Membaca Al-Qur'an Berbasis Android hal yang perlu diperhatikan dalam pembuatan game interaktif antara lain:

1. Bahwa pembelajaran dengan sistem interaktif meningkatkan minat anak dalam memulai proses awal belajar.

2. Games interaktif menjadi suatu alternatif dalam menyampaikan pembelajaran diantara metode-metode lainnya.

3. Menggunakan aplikasi ini sebagai media pembelajaran lebih efektif dan mempermudah pengguna mendalami materi.

4. Guru, Orang tua dan Siswa merasa terbantu dengan kehadiran media pembelajaran menggunakan aplikasi.

5. Dalam merancang game interaktif mempunyai beberapa hal yang harus diperhatikan yaitu edukatif dan tidak monoton.

\section{REFERENSI}

Aditama, D., Rosyid, H., \& Fahriani, N. (2018). Aplikasi Pembelajaran Alfanumerik Untuk Anak Usia PraSekolah Berbasis Android Menggunakan Metode Tesseract-Ocr. J-COSINE, 2(1), 70-76. Retrieved from https://jcosine.if.unram.ac.id/index.php/jcosine/article/view/128/20

Arsyad, M. N., \& Fatmawati, F. (2018). Penerapan Media Pembelajaran Berbasis Multimedia Interaktif Terhadap Mahasiswa IKIP Budi Utomo Malang. JURNAL AGASTYA, 8(2), 188-198. https://doi.org/http://doi.org/10.25273/ajsp.v8i2.2702

Clara, Y., Supriyati, Y., \& Situmorang, R. (2018). Pengembangan Game Interaktif Pada Pembelajaran Tematik di $\begin{array}{lllll}\text { Sekolah Dasar } & \text { (pp. } & \text { 94-98). } & \text { Retrieved }\end{array}$ http://journal.unj.ac.id/unj/index.php/psdpd/article/view/9995/6549

Latifah, F., \& Abimanyu, A. S. (2016). Perancangan aplikasi android rekapitulasi hasil pemilu sementara menggunakan algorithma sequential sercing berbasis mobile. Jurnal Techno Nusa Mandiri, XIII(1), 32-41. Retrieved from https://ejournal.nusamandiri.ac.id/index.php/techno/article/view/215

Lubis, B. O., \& Salim, A. (2016). Aplikasi Android Untuk Menentukan Jarak Terpendek Antar Terminal Di Jakarta. In Sensitif $2016 \quad$ (pp. 87-100). Retrieved from https://repository.bsi.ac.id/index.php/repo/viewitem/741

Marjuni, A., \& Harun, H. (2019). Penggunaan Multimedia Online Dalam Pembelajaran. Jurnal Manajemen Pendidikan, III(36), 194-204. https://doi.org/https://doi.org/10.24252/idaarah.v3i2.10015

Nurrita, T. (2018). Pengembangan Media Pembelajaran untuk Meningkatkan Hasil Belajar Siswa. Misykat, 03, 171-187. https://doi.org/10.33511/misykat.v3i1.52

Sukamto, R. A. (2019). Rekayasa Perangkat Lunak: Terstruktur dan Berorientasi Objek, Edisi Revisi. Bandung: Informatika.

Supriyono, H., Murtiyasa, B., Rahmadzani, R. F., \& Syahriandi, M. (2018). Penerapan Game Edukatif Untuk Meningkakan Motivasi. WARTA LPM, 21(1), 30-39. Retrieved from http://journals.ums.ac.id/index.php/warta/article/view/4939/3909

Wati, R., \& Ernawati, S. (2018). Perencanaan Aplikasi Kamus Bahasa Jawa-Indonesia Berbasis Android. Jurnal TECHNO Nusa Mandiri, 15(2), 93-98. https://doi.org/https://doi.org/10.33480/techno.v15i2.17 